\title{
STUDENTS' DIFFICULTIES IN TRANSLATING NARRATIVE TEXT FROM ENGLISH INTO INDONESIA AT IAIN BUKITTINGGI
}

\author{
Yenita Hastuti \\ LAIN Bukittinggi \\ yenitahastuti14@gmail.com \\ Absharini Kardena \\ LAIN Bukittinggi \\ absharinikardena@yahoo.co.id \\ Eliza \\ LAIN Bukittinggi \\ liza_chio89@yahoo.co.id
}

\begin{abstract}
The research is due to several problems found in the field; the students assumed that narrative text was the difficult text to translate. It happened because the students translate the text literally, also the students were lack of vocabularies in translating the text. This research aims to find out the causes of students' problems in translating narrative text. The research used descriptive method with a quantitative approach in which the sample of the research was 55 fifth semester students of English Education Study Program at IAIN Bukittinggi, academic year $2018 / 2019$, by using questionnaires as the instrument of this research. The findings of the research showed that there are two factors causing problems in translating narrative text from English into Indonesian; they are linguistic factors and non-linguistic factors. It is proved by the highest percentage of students' difficulties which is $55 \%$ in linguistic factors and $52 \%$ in nonlinguistic factors.
\end{abstract}

Key words: Translation, Narrative, Text

\section{A. INTRODUCTION}

ranslation becomes a primary necessity for students who learn English as a foreign language. Translation does not only transform one language to another one, but also

gives exact information to convey its message well. T. Bell (1991) states that translation is the process of rendering meaning, ideas, or message of a text from one language to other language. There are some considerations which follow this process, which mainly related to the accuracy, clarity and naturalness of the meaning, ideas, or messages of the translation. It means that it is an important thing to be considered whether the readers of the target text accept equivalent information as the readers of the source text do. A good translation should sound like the original text. Budianto and Fardhani (2010) state that translation flows naturally as if it is originally written in the target language. The grammar and vocabulary used in the translation are not strange and awkward. Therefore, in doing the translation one should make sure that he or she has taken several considerations to make 
some adjustments in the context of the target language in order to result in good and natural translation.

Based on the preliminary research conducted on February $3^{\text {rd }} 2019$, through interview to $5^{\text {th }}$ semester students at IAIN Bukittinggi who had learned translation in the previous semester, the researchers found some problems. The first problem of this research was some students considered that translation is hard to be learned and they have lacks of vocabularies so it makes them difficult to translate the text. The first problem in line with the theory which found on the of according to Irwandi (2019) in which, the further obstacle which occurs in vocabulary learning process is the young learners are difficult in utilizing the applicable words in context. For instance, in differentiating two words overlapping in meaning. 'Make' and 'do' are cases in the point: you make a cup coffee and you do your homework. Both sentences have opposite meaning. 'Make' is used for creating or producing something, wheareas 'Do' is used for actions. Unfortunately, most of young learners are difficult to differentiate both words if the teacher does not educate them in using appropriate words in context. It is a common problem which happens. However, the common problem will be serious when the young learners have been adult learners because the failure will be used in their daily activity. The second problem was the students usually translated the text literally and they can not comprehend the meaning of the text. However they learnt how to translate the text well. Their translation result was still unnatural. The last problem found was the students assumed that text is more difficult to be translated, especially narrative text which is quite difficult to be translated. In the narrative text the students confused to retain the meaning from source language to target language because mostly in narrative text contains idioms and make the students difficult ro retain the implicit meaning. Therefore, it makes the students' translation not appropriate to target language.

Based on the problem above, it was important to do this research because it is a scientific reason to conduct a research about translating narrative text in English into Indonesia entitled, Students' Translation on Narrative Text from English into Indonesian of English Education Study Program at IAIN Bukittinggi".

\section{B. REVIEW OF LITERATURE}

\section{Translation}

This part describes the theories used as the basic in this paper, which consists of theories about translation, kinds of translations, and the causes of translations.

Newmark (1988) states that translation is rendering the meaning of a text into another language in the way that the author intended the text. The other definition comes from 
Catford (1965) who also said that translation is an operation performed on languages: a process of subtituting a text in one language for a text in another. According to them the result of translation should use closest natural equivalent meaning either in the meaning orchange of a language from the source language to target language with the purpose of the text remains the equivalent meaning.

\section{Kinds of Translation}

According to Larson (1984), there are two main kinds of translation, there are: Formbased translations, meaning-based translation. Form-based translations attempt to follow the form of the source language and are known as literal translations. It means that the translate form based translation depends on the source language. Literal translation is internal translation which is lead the translator with form word by word. For instance, when a translator attempts to translate a sentence in English:

"You-all shouldn't be doing that!", the translator produce the sentence into Indonesan as:

“Kamu semua harus tidak melakukan itu!" The speaker of the target language may comprehend the meaning word by word of the form. Meaning-based translation means makes every effort to communicate the meaning of the source language text in the natural forms of the target language. A truly idiomatic translation does not sound like a translatethis translation use the natural from the receptor language but the idiomatic translation both in the grammatical construction and the choice of the lexical meaning. It means that translating a language that should be followed by the target language form in order to be more naturally. For instance, in English: "He is a book-worm". If a translator translate it literally into Indonesian would be “dia adalah cacing buku", but idiomatically it would be: "dia seorang kutu buku".

\section{Causes in Translating}

According to Nida and Taber (1982) say that many factors are crucial to the process of translating and no explanation of translating can claim to comprehensive if these factors are not systematically considered. Translation is a complex process, involving linguistic and nonlinguistic factors. Translation difficulties they are follows:Linguistic Factors exert a direct and crucial influence upon the processof translation. Each of the linguistic factors, lexical, syntactic and textual, can interfere with translation. It can safely be assumed that interlingual differences constitute a main source of translation difficulties. There are five problems in in translating of meaning such as lexical meaning, grammatical meaning, contextual meaning, textual meaning and socio cultural meaning. First, Lexical meaning is a meaning which is 
mentioned in the dictionary. Lexical meaning of words are out of the context.Second, grammatical meaning is the relationship of the parts of language in the wider units, for example the relationship between one word and other words in phrase or clause.Third contextual meaning is the relationship between the utterences and the situation where the utterences are used. Fourth textual meaning is related to the connect of a text. It is found in a discourse or a text. Then socio-cultural meaningthe meaning has close relationship to social situation and language user's cultural background. In Non linguistic Factors involves the knowledge in ideology, cultural, historical, political-social, chemistry, science, technical biology, medical, agricultural, and economics. Translating work to bridge the cultural gap between two worlds and make communication possible between different linguistic communities. According to Kardena (2016), the teacher should be able to involve cultural values in teaching English. As explained by Hesar, et al in Kardena (2012: 46), the learners should be encouraged to understand a new culture while maintaining their own culture.

\section{Narrative Text}

According to Zubad (2012) narrative text is a story with complication or problematic events and it tries to find the resolutions to solve the problems. An important part of narrative text is the narrative mode, the set of methods used to communicate the narrative through a process narration.

\section{Generic Structure of Narrative Text}

Orientation sets the scene where and when the story happened and introduces theparticipants of the story: who and what is involved in the story. Complicationtells the beginning of the problems which leads to the crisis (climax) of the main participants. Resolution the problem (the crisis) is resolved, either in a happy ending or in a sad (tragic) ending. Then re-orientation/coda this is a closing remark to the story and it is optional. It consists of a moral lesson, advice or teaching from the writer.

\section{METHOD}

This research used descriptive quantitative method. Descriptive quantitative research refers the semantic phenomenon via statistical, mathematical or numerical. The researchers analyzed the phenomenon that was found during the research.

The research was conducted at fifth semester students of English Education Study Program in IAIN Bukittinggi. The researcher aimed to know the students' translation in translating class of English Education Study Program in IAIN Bukittinggi. 


\section{Population and Sample}

\section{Population}

Population is a group of researcher decided for doing the study that consists of individuals who have the same characteristics (Creswell, 2012). The population of this research was fifth semester students that took Translation subject academic years 2018/2019 of English Education Study Program of IAIN Bukittinggi.

\section{Sample}

According to Sugiyono, sample is a part of the population itself. For example, the population of one inhabitant in one area, then the sample is half of the population in the habitant (Sugiyono 2015). This research used total sampling techniques. From the population, the researcher used total sampling to do the resarch because the population is less than a houndred person and translation is an elective subject and only 55 students took the subject. Suharsimi (1998) states that total sampling is the sample take all of the subject in from the population. The reason was the population is less than a hundred person. Therefore the number of sample is the same as the population.

\section{Instrument}

Instrument is also important, it is device to get the data. It should be chosen according to the data we need. It is needed to get result, so the researcher get a conclusion.For answer the research question, this research used questionnaire. According to Sugiyono (2014), questionnaire explained the technique of data collection carried out by giving a set of questions or statements to the respondent to answer.The research used closed ended questions. Closed ended questions are questions that expect short answer and expect respondents to chose one alternative from the answers to each question that has been available. Closed ended questions help respondents to answer quickly, and also make it easier for researchers to analyze data on all collected questionnaire.

\section{Procedures}

In line with the research design before, the data were taken from questionnaire. Firstly, the researchers gave the questionnaire to the sample (students). Secondly, the researchers gave explanation how to fill the questionnaire next. Thirdly, the researchers gave the time to the students for fill the questionnaire. The last, the researchers collected the test and questionnaire and analyzed the data.

\section{Data Analysis Techniques}

The analysis of data was used at the end of the research. The data were analyzed by using descriptive statistic. In this analysis, there were important steps; technique of the data anlysis 
is a process to analyze the data that had been collected to get the conclusion. The first step was tabulating, the researcher accounted the data and describe it in the table. The next the researcher step calculated frequency (f) of respondents' answer, and the researcher gave interpretation by following table (Sugiyono, 2015):

Table 1

The Data Interpretation

\begin{tabular}{lc}
\hline Percentage & Interpretation \\
\hline $0 \%$ & Nothing \\
$1 \%-25 \%$ & So little \\
$50 \%$ & Fraction \\
$51 \%-75 \%$ & Most \\
$76 \%-99 \%$ & In General \\
$100 \%$ & All \\
\hline
\end{tabular}

At the last, the researcher made conclusion based on the students result in translating narrative text English into Indonesia.

\section{FINDINGS AND DISCUSSION}

\section{Findings}

The findings are devided into two factors; according to Nida and Taber (1986), there are two factors, lingusitic factors and non linguistic factors that influence students' difficulties in translating. The following description of students' difficulties in translating text each factor:

\section{Non Linguistic factors}

In the theory according to Nida and Taber (1986) in non linguistic factors consists of five indicators there are; lexical, grammatical, contextual,textual and grammatical.In the questtionnaire in non linguistic factors there were seven statements. The result of students' answer for causes in non linguistic factors are displayed with using in the table 2 as follows:

Table 2 The Result of Questionnaire in Non Linguistic Factors

\begin{tabular}{|c|c|c|c|c|c|c|}
\hline No & Item Questionnaires & Option & $\mathbf{F}$ & $\mathbf{X}$ & $\mathbf{F x}$ & Percentage $\sum \mathrm{fx} / \mathrm{n} \times 100$ \\
\hline \multirow[t]{5}{*}{$\overline{1}$} & \multirow{4}{*}{$\begin{array}{l}\text { Saya mengalami kesulitan dalam } \\
\text { menerjemahkan kata-kata yang } \\
\text { berhubungan dengan budaya. }\end{array}$} & Often & 14 & 1 & 14 & \multirow[t]{4}{*}{$106 / 220 \times 100$} \\
\hline & & Sometimes & 32 & 2 & 64 & \\
\hline & & Seldom & 8 & 3 & 24 & \\
\hline & & Never & 1 & 4 & 4 & \\
\hline & Total & & 55 & & 106 & \multirow{4}{*}{$\begin{array}{c}48 \% \\
108 / / 220 \times 100\end{array}$} \\
\hline \multirow{3}{*}{2} & \multirow{3}{*}{$\begin{array}{l}\text { Saya mengalami kesulitan } \\
\text { menerjemahkan teks yang berkaitan } \\
\text { dengan sejarah (historical) }\end{array}$} & Often & 12 & 1 & 12 & \\
\hline & & Sometimes & 34 & 2 & 68 & \\
\hline & & Seldom & 8 & 3 & 24 & \\
\hline
\end{tabular}


Yenita. Absharini, Elisa, Students' Difficulties in Translating Narrative...

\begin{tabular}{|c|c|c|c|c|c|c|}
\hline \multirow{2}{*}{\multicolumn{2}{|c|}{ Total }} & Never & 1 & 4 & 4 & \multirow[b]{2}{*}{$49 \%$} \\
\hline & & & 55 & & 108 & \\
\hline 3 & Saya mengalami kesulitan dalam & Often & 24 & 1 & 24 & \multirow{4}{*}{$96 / 220 \times 100$} \\
\hline & menerjemahkan kata-kata yang & Sometimes & 22 & 2 & 44 & \\
\hline & \multirow{2}{*}{ berhubungan dengan agricultural } & Seldom & 8 & 3 & 24 & \\
\hline & & Never & 1 & 4 & 4 & \\
\hline & Total & & 55 & & 96 & $44 \%$ \\
\hline \multirow[t]{5}{*}{4} & Saya mengalami kesulitan dalam & Often & 18 & 1 & 18 & \multirow{4}{*}{$102 / 220 \times 100$} \\
\hline & menerjemahkan katakata yang & Sometime & 28 & 2 & 56 & \\
\hline & \multirow{2}{*}{ berhubungan dengan bidang sains } & Seldom & 8 & 3 & 24 & \\
\hline & & Never & 1 & 4 & 4 & \\
\hline & Total & & 55 & & 102 & $46 \%$ \\
\hline \multirow[t]{5}{*}{5} & \multirow{4}{*}{$\begin{array}{l}\text { Saya mengalami kesulitan dalam } \\
\text { menerjemahkan kalimat yang } \\
\text { berhubungan dengan bidang } \\
\text { ekonomi }\end{array}$} & Often & 10 & 1 & 10 & \multirow{4}{*}{$115 / 220 \times 100$} \\
\hline & & Sometimes & 31 & 2 & 62 & \\
\hline & & Seldom & 13 & 3 & 39 & \\
\hline & & Never & 1 & 4 & 4 & \\
\hline & Total & & 55 & & 115 & \multirow{5}{*}{$158 / 220 \times 100$} \\
\hline \multirow[t]{5}{*}{6} & \multirow{4}{*}{$\begin{array}{l}\text { Saya mengalami kesulitan dalam } \\
\text { menerjemahkan kata-kata yang } \\
\text { berhubungan dengan social. }\end{array}$} & Often & 0 & 1 & 0 & \\
\hline & & Sometimes & 13 & 2 & 26 & \\
\hline & & Seldom & 36 & 3 & 108 & \\
\hline & & Never & 6 & 4 & 24 & \\
\hline & Total & & 55 & & 158 & $72 \%$ \\
\hline \multirow[t]{6}{*}{7} & Saya mengalami kesulitan dalam & Often & 10 & 1 & 10 & \multirow{4}{*}{$117 / 220 \times 100$} \\
\hline & menyesuaikan pemilihan kata yang & Sometimes & 31 & 2 & 62 & \\
\hline & tepat dalam menerjemahkan teks & Seldom & 11 & 3 & 33 & \\
\hline & yang berhubungan dengan ideologi & Never & 3 & 4 & 12 & \\
\hline & Total & & 55 & & 117 & $53 \%$ \\
\hline & AVERAGE & & & & 362 & $52 \%$ \\
\hline
\end{tabular}

(Source: research data)

Based on the table 2 there were 55 students' responses. In the questionnaire, there were 7 statements about causes of students translating in non linguistic factors. The data showed that there were 18 respondents who answered 'always'. Then, 14 respondents answered 'often', 32 respondents answered 'sometimes', 8 respondents answered 'seldom' and one respondents answered 'never'. In addition, the percentage of the first statement is $48 \%$ which means that they had fraction category as a causes toward the first statement.

The second, point ilustrated the majority of the students choose option 'sometimes' with 34 respondents. Then, there were 12 respondents who chose option 'often' toward the statements. The table also showed 8 respondents chose 'seldom', one respondent chose 'never' toward the statements. Then, the percentage of the second statement is $49 \%$ which means the students got fraction category and the students consider this statement as a cause in translating toward the second statement.

The third point, explained that popular answered was 'often' with 24 respondents chose it. Then 22 respondent chose 'sometimes' and 8 respondents chose 'seldom' also one 
respondent chose 'never' with the statements. Then, the percentage of the third statements is $44 \%$ which means the students got fraction category toward the third statement. Thus this statement was one of the causes of the students' difficulties in translating.

The fourth statement showed that the majority of the respondents answered 'sometimes', 28 respondents, and the minority of respondents answered 'seldom', with 1 respondent. Then, there were 18 respondents who chose 'sometimes' with the statement, and 8 respondents chose 'seldom'. In brief, the percentage of this item is $46 \%$ and it means the students had fraction category as a cause in this statement.

The fifth statement showed that popular answer was 'sometimes', 31 respondents. Then 10 respondents answered 'often', 13 respondents chose seldom and one respondent answered 'never'. In addition, the percentage of this statement is $52 \%$ and it means that the students got mostly as a causes in in translating toward the statements.

The sixth statement that there were that majority of respondents, 36 respondents who chose 'seldom' toward the statement. Then, there were 13 respondents who chose 'sometimes' with the statement, 6 respondents chose 'never' and none respondent chose 'often' toward the statements. In conclusion, the percentage of this statements is $72 \%$ which means that the respondents got most category toward the statement.

For the last item in non linguistic factors the majority of respondents chose 'sometime' (31 respondents), 11 respondents chose 'seldom' with the statement, 10 respondents chose 'often' and 3 respondents chose 'never' with the statment. Thus, the percentage item is 53\% and it explained that in mostly the students considered the last statement as the cause.

In conclusion, the mean of non linguistic factors is $51 \%$ and it shows that the students got mostly as a cause in non linguistic factors which means that students explained fraction as a cause in translating.

\section{Linguistic factor}

In the theory according to Nida and Taber (1986) in linguistic factors consists of knowledge in ideology, historical, political, social, technical, biology, medical, agricultural, and economics. In the questionnaire linguistic factors there were seven statements. The result of students' answer for causes in non linguistic factors are displayed with table 3 as follows:

Table 3 The Number of Students Causes of Difficulties in Linguistic Factors

\begin{tabular}{|c|c|c|c|c|c|c|}
\hline No & Item Questionnaires & Option & $\mathrm{F}$ & $\mathrm{X}$ & fx & Percentage $\sum \mathrm{fx} / \mathrm{n} \times 100$ \\
\hline \multirow[t]{3}{*}{8} & Saya menemukan kata-kata yang & Often & 18 & 1 & 18 & \multirow{3}{*}{$118 / 220 \times 100$} \\
\hline & memiliki arti ganda sehingga & Sometimes & 17 & 2 & 34 & \\
\hline & menyulitkan saya dalam & Seldom & 14 & 3 & 42 & \\
\hline
\end{tabular}




\begin{tabular}{|c|c|c|c|c|c|c|}
\hline & $\begin{array}{l}\text { menemukan makna yang benar } \\
\text { kebahasa target }\end{array}$ & Never & 6 & 4 & 24 & \\
\hline & Total & & 55 & & 118 & $54 \%$ \\
\hline \multirow[t]{5}{*}{9} & Saya mengalami kesulitan dalam & Often & 8 & 1 & 8 & \multirow{4}{*}{$125 / 220 \times 100$} \\
\hline & menyesuaikan pola kalimat yang & Sometimes & 29 & 2 & 58 & \\
\hline & telah diterjemahkan dari Bahasa & Seldom & 13 & 3 & 39 & \\
\hline & $\begin{array}{l}\text { Inggris ke pola kalimat Bahasa } \\
\text { Indonesia }\end{array}$ & Never & 5 & 4 & 20 & \\
\hline & Total & & 55 & & 125 & $56 \%$ \\
\hline \multirow{5}{*}{10} & Saya mengalami kesulitan dalam & Often & 8 & 1 & 8 & \multirow{4}{*}{$128 / 220 \times 100$} \\
\hline & mengartikan keselurunan kalimat & Sometimes & 24 & 2 & 48 & \\
\hline & per katanya & Seldom & 20 & 3 & 60 & \\
\hline & & Never & 3 & 4 & 12 & \\
\hline & Total & & 55 & & 96 & $44 \%$ \\
\hline \multirow[t]{5}{*}{11} & Saya mengalami kesulitan dalam & Often & 8 & 1 & 8 & \multirow{4}{*}{$126 / 220 \times 100$} \\
\hline & merangkai kata-kata dalam Bahasa & Sometimes & 25 & 2 & 50 & \\
\hline & Indonesia sehingga menghasilkan & Seldom & 20 & 3 & 60 & \\
\hline & $\begin{array}{l}\text { kalimat rancuh yang sulit } \\
\text { dipahami pembaca kebahasa } \\
\text { target }\end{array}$ & Never & 2 & 4 & 8 & \\
\hline & Total & & 55 & & 126 & $57 \%$ \\
\hline \multirow[t]{5}{*}{12} & \multirow{4}{*}{$\begin{array}{l}\text { Saya mengalami kesulitan dalam } \\
\text { mencari ketertaitan makna setiap } \\
\text { kalimat dalam menerjemahkan } \\
\text { teks ke bahasa target }\end{array}$} & Often & 12 & 1 & 12 & \\
\hline & & Sometimes & 26 & 2 & 52 & \\
\hline & & Seldom & 11 & 3 & 33 & \\
\hline & & Never & 6 & 4 & 24 & $121 / 220 \times 100$ \\
\hline & Total & & 55 & & 121 & $55 \%$ \\
\hline \multirow[t]{5}{*}{13} & \multirow{4}{*}{$\begin{array}{l}\text { Saya mengalami kesulitan dalam } \\
\text { menerjemahkan idiom }\end{array}$} & Often & 21 & 1 & 21 & \multirow{4}{*}{$104 / 220 \times 100$} \\
\hline & & Sometimes & 21 & 2 & 42 & \\
\hline & & Seldom & 11 & 3 & 33 & \\
\hline & & Never & 2 & 4 & 8 & \\
\hline & Total & & 55 & & 104 & $47 \%$ \\
\hline \multirow[t]{6}{*}{14} & $\begin{array}{l}\text { Saya mengalami kesulitan dalam } \\
\text { menerjemahkan kata atau kalimat }\end{array}$ & Often & 5 & 1 & 6 & \multirow{4}{*}{$131 / 220 \times 100$} \\
\hline & sesuai dengan topik atau konteks & Sometimes & 28 & 2 & 56 & \\
\hline & yang di dalam teks ke bahasa & Seldom & 15 & 3 & 45 & \\
\hline & target & Never & 6 & 4 & 24 & \\
\hline & Total & & 55 & & 131 & $60 \%$ \\
\hline & AVERAGE & & & & 385 & $55 \%$ \\
\hline
\end{tabular}

(Source: research data)

Based on the table 3 in questionnaire there were 7 statements about causes of students translating in linguistic factors. The first statement that there were in linguistic factor based on the table above, the first item explained 18 respondents chose 'often' with statements. Then, 17 respondents chose 'sometimes' for the statement, 14 respondents chose 'seldom', and 6 respondents chose 'never' with the statements. Then, the percentage of the first statements in 
linguistic factors is $54 \%$ which means that this statement got most category as the cause in translating.

The second statement showed that the popular answers were 29 respondents who chose 'sometimes', 13 respondents chose 'seldom', 8 respondents chose 'often' and 5 respondents chose 'never' with the statement. In conclusion, the percentage of the data is $57 \%$ which means that the students had most category as the cause of the statements.

The third item showed that, the popular answered, 24 respondents chose 'sometimes', 20 respondents chose 'seldom, 8 respondents chose 'often', and two respondents chose 'never' in the statement. The percentage of the statement is $44 \%$ which means that the students got fraction category as the cause in translating.

The fourth statements showed that of the majority of the respondents' answers, 25 respondents chose 'sometimes' toward the statements, 20 respondents chose 'seldom', 8 respondents chose 'often' and two respondents chose 'never'. In brief, the percentage of the statement is $57 \%$ which has most category as the causes in translating.

The fifth statements showed that the majority of the respondents answered toward the statement, there were 26 respondents who chose 'sometimes', 11 respondents chose 'seldom', 12 respondents chose 'often', and 6 respondents chose 'never'. Thus, the percentage of the statement is $55 \%$ which had most category as the causes in translating.

The sixth, based on the respondents' answers, it showed that option 'often' and 'sometimes' are equal. There were 21 respondents that chose 'often', and 21 respondents chose 'sometimes', then, 11 respondents chose 'seldom', and two persons chose 'never' with the statement. In conclusion, the percentage of the data is $47 \%$ which means that the students had fraction category as the causes in translating.

The last item explained that of the majority of respondents' answers, 28 respondents chose 'sometimes' with the statement, 15 respondents chose 'seldom' toward the statement, the respondents' answers in 'often' and 'never' are equal, 6 respondents chose 'sometimes' and 6 respondents chose 'never' toward the statement. In brief, the percentage of this statement is $60 \%$ and it explains that the students have most category as the causes in translating toward the last statement.

In conclusion, the mean of linguistic factor statements is $55 \%$ and non linguisic factors is $52 \%$. If it is interpreted in table 1 , it is in the range 51\%-75\% (most category). It means that linguistic and non linguistic factors are the the most difficulties aspect with $52 \%$ and $55 \%$ respectively. 


\section{Discussion}

Based on the result, after analyzing the data in non linguistic factors and in linguistic factors, the most difficulties are the social value and contextual meaning factors respectively.

In translating non-linguistic factors according to the students answer from the questionaire found that the causes of students dificulties factors were in social aspect and ideology. Thus, it means that this is one of the cause in translating. This statement in line with the theory stated by Nida and Taber, they involves social value as a causes of students' difficulties in translating. Beside ideology, cultural, historical, political-social, chemistry, science, technical biology, medical, agricultural, and economics also as the causes of translating.

As a matter of fact, this research relates to the previous studies by Dedek (2018), in her research entitled An Anlysis of Students Difficulties in Translating Argumentative at The Second Grade in MAN Tebing Tinggi,the expect found that the students had difficulties in translating words related to ideological values, technique values, and related to economy value. In the other study according Roza(2019) the finding reveals that students deploy four macro negotiation strategies when explicating the concepts and examples in translation class. They keep using English as they can as a medium of communication and sometimes alter their languages with Indonesian and local language as needed in order to deliver the message. The researcher finds the negotiation strategies applied by interlocutors during classroom interaction are through; (1) deploying envoicing strategies of word coinage, foreignization, code-switching, and code mixing.; (2) employing recontextualization strategies by the use of the feature of linguistic form like saying a formulaic Islamic greeting in Arabic before speaking; (3) using interactional strategies through confirmation check, clarification request, and recast; (4) applying entextualization strategies by using simplification in communication by more competent students and leveling by less competent speakers.

In linguistic factors, the students found that the causes of students' difficulties factors were grammatical, lexical, contextual, and textual. It means that the causes of students' difficulties in translating text is almost in linguistic factors. According to Nababan, lexical meaning is a meaning of words are out of the context. It is suitabale with Nababan this reseach found that one of the causes of students' difficulties in translating is lexical. That is why the students assume narrative text is quite difficult to be translated because narrative text contained of idiom.

In fact, other research is also similar as the research conducted by Sari, 2010; Dedek, 2018, the researcher found that the students had difficulties in finding out the suitable terms 
with the context of sentences the students were difficult to find words not in the dictionary, and the students were difficult to adjust sentence patterns that had been translated from English into Indonesia. In the other study according by Veni (2018). According to Veni, some experts limit the context to mean context by interlocutors, their relationship to one another and the setting. How old are you? is asked by a doctor to the patient when filling the medical record is pragmatically appropriate, grammatically accurate and semantically meaningful. On the other hand, if the same question is addressed to a stranger whom one may meet accidentally, it is semantically meaningful and grammatically accurate, but pragmatically inappropriate in that context. (Takashima and Sugiura, 2000). Correct language thus various according to the context. Therefore, it is clear that for communicative instruction is not necessary to help students gain mastery over the target language.

The last findings regarding the study was that the students were difficult to interpret the whole sentence even though the students know the meaning of the sentence and the students were difficult to understan the meaning of the source language so it makes the difficultiy forthe students translate to the target language. This appears because the students translate the text literally and lack of the context of the text that they needed to have in translating and this finding in line with theory propossed by Mellan Melyanni (2014). According Melyann reading is also a comprehension process when people try to understand the messages that the writer convey in the text. Comprehension is the central goal of reading and all cognitive processing involved in reading is related to this fundamental goal. Reading is an interactive process since the text provides information that the writer wants the reader to know and the reader in the process of constructing meaning related the text to their prior knowledge. Reading is also a strategic process in a way that readers use different strategies to anticipate the text. Reading is flexible, purposeful, evaluative and learning process. Finally, reading is a linguistic process where it linguistic knowledge (morphology, syntax and semantic) is required.

In conclusion, linguistic factors is the main factors toward the students' difficulties in translating narrative text of English Education Study Program at IAIN Bukittinggi year $2019 / 2020$.

\section{E. CONCLUSION}

Based on the research question, the researchers conclude that, the students causes are categorized as most where non-linguisic factors and in linguistic factors have 52\% and 55\% respectively. It means that linguistic factors are considered as the main causes of students' difficulties in translating narrative text from English into Indonesian. 
Yenita. Absharini, Elisa, Students' Difficulties in Translating Narrative...

\section{REFERENCES}

Bell T. Roger. 1991. Translation and Translating: Theory and practice. London and New York: Longman.

Basil Hatim and J, Munday. 2004. Translation an Advanced Resource Book. Newyork : Routledge

Cohen, Louis, Lawrence Manion and Keith Morrison. 2007. Research Methods in Education. London : Routledge.

Dedek. 2018. The Analysis Of Students Difficulties In Translating Argumentative Text From English to Indonesian At The Second Grade Students of Man Tebing Tinggi . Medan. Uin Medan.

Irwandi, Et All. 2018. Teaching Vocabulary In Contextualization For Young Learners. Bukittinggi. IAIN Bukittinggi.

John W, Creswell .2009. Educational Research: Planning, Conducting, and Evaluating Quantitative and Qualitative Research. USA : PEARSON.

Kardena. Absharini 2016.Teacher's Role as A Promoter of Multicultural Perspective: A Case In Teaching English as A Foreign Language. Padang.Proceeding of ISELT.

Kardimin. 2017. Ragam Penerjemahan. Vol. 2. NO.1 page.192

L.Larson, Mildred. 1984. Meaning-Based Translation: A Guide to Croos-Language Equivalence. London : University of America.

Newmark, Peter. 1981. Approaches to translation. England: Pergamon Press.

Melani, Melyann. 2014. Defining Reading Skills And Strategies In Formulating A Model For Teacbing Reading In Indonesion Context. Padang. Proceeding of SELT.

Nida, Eugine. A and Taber, Charles. A, 1974. The Theory and Practice of translation. E.J Brill : Leiden.

Nurul, Yaqin Zubad. 2012. Bahasa Indonesia Keilmuan. Malang : UIN-MALIKI PRESS.

PandeyMeenuMishra, and Pandey Prabhat. 2015. Research Methodology: Tools and Techniques. Romania: Bridge Center. 
Volume 6, Number 1, June 2020

Roza. Veni. 2019. Translingual Negotiation Strategies Used by English Students to Build Classroom Interaction In A Translation Class. Bukittinggi. IAIN Bukittinggi.

Roza. Veni. 2018. From Grammar to Grammaring inTeaching Grammar. Bandung. UIN Sunan Gunung Djati. Proceeding of Bandung English Language Teaching Internation Conference (BELTIC).

Sari. 2010. Students Difficulties in Translating a Text on Nenwspaper at Sixth Semester Students of English Study Program at University of Pasir Pengaraian. Pasir Pengaraian. University of Pasir Pengaraian.

Sugiyono. 2015. Metode Penelitian Pendidikan Pendekatan Kuantitatif, Kualitatif, R\&D. Yogyakarta : Alfabeta Bandung.

Syamsudin. 2006. Metode Penelitian Pendidikan Bahasa. Bandung : Rosdakarya

WallimanNicholas, 2011. Research Methods the Basics, USA and Canada: Routledge. 